\title{
SIKAP SISWA TERHADAP PERAN GURU BIMBINGAN DAN KONSELING
}

\author{
Oleh: \\ Rosnawati $^{(1)}$, Sudarmi Suud ${ }^{2)}$, Jahada $^{3)}$ \\ 1) 2) 3) Jurusan Bimbingan dan Konseling \\ Fakultas Keguruan dan Ilmu Pendidikan, Universitas Halu Oleo \\ Email: rosnaallfi@gmail.com
}

\begin{abstract}
ABSTRAK
Tujuan penelitian adalah untuk mendeskripsikan Sikap Siswa Terhadap Peran Guru BK Pada Jurusan Geologi di SMK Negeri 6 Kendari. Jenis penelitian adalah deskriptif kuantitatif. Populasi dalam penelitian ini adalah seluruh siswa Jurusan Geologi di SMK Negeri 6 Kendari yang berjumlah 132 orang.Sedangkan sampel penelitian sebanyak 26 orang yang dipilih dengan teknik proportional random sampling. Teknik pengumpulan data menggunakan skala sikap yang berjumlah 60 butir pernyataan yang kemudian dianalisis menggunakan teknik deksriptif Persentase. Hasil penelitian menunjukan bahwa mayoritas siswa $61.53 \%$ atau 16 orang siswa dinyatakan memiliki sikap yang cukup baik terhadap peran guru BK di sekolah, yaitu dengan perolehan skor berada pada rentang skor (109-141) pada kategori cukup baik, serta perolehan rerata skor angket sebesar 136.7 berada pada rentang skor (109-141) pada kategori cukup baik. Dengan demikian, dapat disimpulkan bahwa sikap siswa terhadap peran guru BK pada Jurusan Geologi di SMK Negeri 6 kendari berada pada kategori cukup baik.
\end{abstract}

Kata Kunci: Sikap Siswa, Peran Guru Bk

\section{THE STUDENTS' ATTITUDES TOWARD THE ROLE OF GUIDANCE AND COUNSELING TEACHER}

\begin{abstract}
The purpose of the research was to describe the students' attitudes toward the role of guidance and counseling teacher in the department of mining and Geology of SMK Negeri 6 Kendari. The type of the research was descriptive quantitative. The population of the research was 132 students of Vocational High School 6 Kendari. The samples of the research were 26 students who have been chosen by Purposive Random Sampling. The technique of data analysis used descriptive presentation technique. The results of the research reveal that 16 students (or 61.53\%) had good enough attitudes toward the role of the guidance and counseling teacher in the school. The scores in ranging from 109 to 141, and the scores indicate that they are in good enough category. The average score of the questionnaires is 136.7 in the range of $109-141$. The score indicates that it is in a good enough category. The results can therefore be concluded that the students' attitude toward the role of Guidance and Counseling Teacher in the Department of Mining and Geology is in a good enough category.
\end{abstract}

Keywords: Students Attitude, The Role of Guidance and Counseling Teacher. 


\section{Pendahuluan}

Tugas dan tanggung jawab guru bimbingan dan konseling merupakan upaya proaktif dan sistematik dalam memfasilitasi individu mencapai tingkat perkembangan yang optimal, pengembangan perilaku yang efektif, pengembangan lingkungan, dan peningkatan fungsi atau manfaat individu dalam lingkungannya. Semua perubahan perilaku tersebut merupakan proses perkembangan individu, yakni proses interaksi antara individu dengan lingkungan melalui interaksi yang sehat dan produktif. Guru bimbingan dan konseling (BK) memegang tugas dan tanggung jawab yang penting untuk mengembangkan lingkungan, membangun interaksi dinamis antara individu dengan lingkungan, membelajarkan individu untuk mengembangkan, merubah dan memerbaiki perilaku.

Pada umumnya, guru BK bertanggung jawab dalam melaksanakan bimbingan pendidikan (educational guidance) dan bimbingan dalam masalah-masalah pribadi (personal guidance). Guru BK juga memunyai tugas menetapkan kasus-kasus yang perlu mendapatkan perhatiannya segera dengan jalan meneliti catatan-catatan sekolah, mengadakan pertemuan-pertemuan dengan anggota-anggota staff sekolah lainnya, melaksanakan observasi yang dilakukannya sendiri dan menggunakan teknik sosiometrik (Daryanto, 2015: 35).

Dengan demikian, dapat dipahami bahwa peran guru BK adalah melaksanakan tugas dan tanggung jawab secara operasional melalui upaya, usaha atau ikhtiar sesuai kewenangannya untuk mencapai tujuan yang telah ditetapkan sebelumnya. Peran ini tidak hanya bersifat formatif akan tetapi bersifat praktis dengan spesifikasi tertentu, yaitu memberikan bantuan kepada siswa untuk mengembangkan potensi dirinya secara optimal agar siswa tersebut dapat mencapai tingkat perkembangan yang seimbang antara jasmani dan rohaninya.

Ali (2015) menyatakan bahwa sikap merupakan predisposisi emosional yang dipelajari untuk merespon secara konsisten terhadap suatu objek. Sikap merupakan variabel laten yang mendasari, mengarahkan dan memengaruhi perilaku. Sikap tidak identik dengan respons dalam bentuk perilaku, tidak dapat diamati secara langsung tetapi dapat disimpulkan dari konsistensi perilaku yang dapat diamati. Secara operasional, sikap dapat diekspresikan dalam bentuk kata-kata atau tindakan yang merupakan respons reaksi dari sikapnya terhadap objek, baik berupa orang, peristiwa, atau situasi.
Peran guru BK di SMK Negeri 6 Kendari seharusnya adalah berperan sebagai informator (pelaksana cara mengajar dan sumber informasi), organisator (pengelola kegiatan akademik), motivator (pemberian dorongan terhadap peserta didik), fasilitator (pemberian fasilitas dan kemudahan), mediator (sebagai penengah dalam kegiatan belajar) dan evaluator (sebagai otoritas untuk menilai prestasi anak). Peranan guru BK sebagai pelaksana utama yang mengkoordinir semua kegiatan bimbingan dan konseling di sekolah untuk membantu siswa menyelesaikan masalahmasalah yang dihadapi siswa, agar menjadi pribadi yang mandiri, peranan guru BK sangat diperlukan dalam menunjang keberhasilan kegiatan belajar agar dapat berlangsung baik sesuai dengan apayang diharapkan (Salahudin, 2010).

Berdasarkan hasil wawancara terhadap informan penelitian menjelaskan bahwa peran guru BK yang dapat terlihat adalah guru BK sebagai polisi sekolah, tugasnya hanya mengatur, dan memberikan hukuman kepada siswa yang bermasalah, sehingga hal ini menyebabkan siswa cenderung menghindari untuk berurusan dengan guru BK dan bahkan beberapa siswa takut ketika dipanggil untuk datang ke ruang BK. Informan yang lain juga menyatakan bahwa guru BK belum optimal menjalankan perannya dengan baik. Hal ini di indikasikan oleh pelaksanaan tugas guru BK hanya pada batas menasehati siswa-siswa yang bermasalah, sehingga guru BK hanya dianggap sebagai penasehat di sekolah oleh beberapa siswa.

Namun, terdapat pula beberapa informan yang menyatakan bahwa mereka senang mengikuti program layanan yang diselenggarakan oleh guru BK. Siswa-siswa tersebut menyatakan bahwa beberapa program layanan BK telah membantu mereka dalam mengentaskan masalah mereka, seperti masalah rencana penyelesaian studi dan pengembangan karir.

Beberapa informasi di atas mengindikasikan adanya keragaman sikap siswa terhadap peran guru BK, khususnya di Jurusan Geologi Pertambangan SMK Negeri 6 Kendari. Dengan demikian, guna memaknai lebih jauh mengenai sikap siswa terhadap kinerja guru BK maka dilakukan penelitian dengan judul "Sikap Siswa Terhadap Peran Guru BK Pada Jurusan Geologi Pertambangan di SMK Negeri 6 Kendari". Tujuan dari pelaksanaan penelitian ini adalah untuk mengetahui sikap siswa terhadap peran Guru BK Pada Jurusan Geologi di SMK Negeri 6 Kendari. 
Sikap dinyatakan dalam tiga domain $\mathrm{ABC}$, yaitu affect, behavior dan cognition. Affect adalah perasaan yang timbul (senang, tak senang), behavior adalah perilaku yang mengikuti perasaan itu (mendekat, menghindar) dan cognition adalah penilaian terhadap objek sikap (bagus, tidak bagus) (Sarwono, 2009). Selanjutnya, Hadiwinarto (2009: 112) menyatakan bahwa sikap (attitude), berasal dari bahasa italia attitudine, yang berarti cara menempatkan atau membawa diri, atau cara merasakan, jalan pikiran dan perilaku. Melalui sikap, kita memahami proses kesadaran yang menentukan tindakan nyata dan tindakan yang mungkin dilakukan individu dalam kehidupan sosialnya.

Jihad (2013: 102) menyatakan bahwa sikap bermula dari perasaan (sikap atau tidak suka) yang terkait dengan kecenderungan seseorang dalam merespon sesuatu/ objek. Sikap juga sebagai ekspresi dari nilai-nilai atau pandangan hidup yang dimiliki oleh seseorang. Sikap dapat dibentuk, sehingga terjadi perilaku atau tindakan yang diinginkan.

Dengan demikian, dapat disimpulkan bahwa sikap merupakan suatu perasaan yang mencerminkan rasa senang dan tidak senang, cara menempatkan atau membawa diri atau cara merasakan, jalan pikiran, dan perilaku. Melalui sikap, kita memahami proses kesadaran yang menentukan tindakan nyata dan tindakan yang mungkin dilakukan individu dalam kehidupan sosialnya.

Menurut Azwar (2013: 30-36) proses pembentukan dan perubahan sikap adalah sebagai berikut :

\section{Pengalaman pribadi}

Pembentukan kesan atau tanggapan terhadap objek merupakan proses kompleks dalam diri individu yang melibatkan individu yang bersangkutan, situasi dimana tanggapan itu terbentuk dan atribut atau ciri-ciri objektif yang dimiliki oleh stimulus.

2. Pengaruh orang lain yang dianggap penting

Orang lain di sekitar kita merupakan salah satu di antara komponen sosial yang ikut memengaruhi sikap kita. Seseorang yang kita anggap penting, seseorang yang kita harapkan persetujuannya bagi setiap gerak tingkah dan pendapat kita, seseorang yang tidak ingin kita kecewakan atau seseorang yang berarti khusus bagi kita (significant others), akan banyak memengaruhi pembentukan sikap kita terhadap sesuatu. Di antara orang yang biasanya dianggap penting bagi individu adalah orang tua, orang yang status sosialnya lebih tinggi, teman sebaya, teman dekat, guru, teman kerja, isteri atau suami dan lain-lain.

3. Pengaruh kebudayaan

Kebudayaan di mana kita hidup dan dibesarkan memunyai pengaruh besar terhadap pembentukan sikap kita. Apabila kita hidup dalam budaya yang memunyai norma longgar bagi pergaulan heteroseksual, sangat mungkin kita akan memunyai sikap yang mendukung terhadap masalah kebebasan pergaulan heteroseksual. Apabila kita hidup dalam budaya sosial yang sangat mengutamakan kehidupan berkelompok, maka sangat mungkin kita akan memunyai sikap negatif terhadap kehidupan individualisme yang mengutamakan kepentingan perorangan.

\section{Media massa}

Sebagai sarana komunikasi, berbagai bentuk media massa seperti televisi, radio, surat kabar, majalah dan lain lain memunyai pengaruh besar dalam pembentukan opini dan kepercayaan orang. Dalam penyampaian informasi sebagai tugas pokoknya, media massa membawa pula pesan-pesan yang berisi sugesti yang dapat mengarahkan opini seseorang. Adanya informasi baru mengenai sesuatu hal memberikan landasan kognitif baru bagi terbentuknya sikap terhadap hal tersebut. Pesan-pesan sugestif yang dibawa oleh informasi tersebut, apabila cukup kuat, akan memberi dasar afektif dalam menilai sesuatu hal sehingga terbentuklah arah sikap tertentu.

5. Lembaga pendidikan dan lembaga agama

Lembaga pendidikan serta lembaga agama sebagai suatu sistem memunyai pengaruh dalam pembentukan sikap dikarenakan keduanya meletakkan dasar pengertian dan konsep moral dalam diri individu. Pemahaman akan baik dan buruk, garis pemisah antara sesuatu yang boleh dan yang tidak boleh dilakukan, diperoleh dari pendidikan dan dari pusat keagamaan serta ajaran-ajaranya.

6. Pengaruh faktor emosional

Suatu bentuk sikap merupakan pernyataan yang didasari oleh emosi yang berfungsi sebagai semacam penyaluran frustasi atau pengalihan bentuk mekanisme pertahanan ego. Sikap demikian dapat merupakan sikap yang sementara dan segera berlalu sigitu frustasi telah hilang akan tetapi dapat pula merupakan sikap yang lebih persisten dan bertahan lama. Suatu contoh 
bentuk sikap yang didasari oleh faktor emosional adalah prasangka (prejudice).

Faktor-faktor yang memengaruhi pembentukan sikap

Sarwono (2014: 205-206) menyebutkan bahwa ada dua faktor yang memengaruhi pembentukan sikap, yakni:

1. Faktor internal

Faktor-faktor yang terdapat dalam diri orang yang bersangkutan, seperti faktor pilihan. Kita dapat menangkap seluruh rangsangan dari luar melalui persepsi kita, oleh karena itu kita harus memilih rangsangan-rangsangan mana yang akan kita dekati dan mana yang harus dijauhi. Pilihan ini ditentukan oleh motif-motif dan kecenderungan-kecenderungan dalam diri kita. Karena harus memilih inilah kita menyusun sikap positif terhadap satu hal dan membentuk sikap negatif terhadap hal lainya.

2. Faktor Eksternal

Selain faktor-faktor yang terdapat dalam dirisendiri, maka pembentukan sikap ditentukan pula oleh faktor-faktor yang berada di luar :

a. Sifat objek, sikap itu sendiri, bagus, atau jelek dan sebagainya.

b. Kewibawaan orang yang mengemukakan suatu sikap yang sedang mengimunisasi bayi dipasang besar-besar dibagian tempat strategis agar masyarakat terdorong untuk mengimunisasi anak-anak balita mereka.

c. Sifat orang-orang atau kelompok yang mendukung sikap tersebut.

d. Media komunikasi yang digunakan dalam menyampaikan sikap.

e. Situasi pada saat sikap itu dibentuk.

\section{Deskripsi peran guru BK}

Peranan bimbingan dan konseling (BK) di sekolah adalah memerlancar usaha-usaha sekolah dalam mencapai tujuan pendidikan. Usaha untuk mencapai tujuan ini sering mengalami hambatan, dan ini terlihat pada anak-anak didik: mereka tidak bisa mengikuti program-program pendidikan di sekolah disebabkan karena mereka mengalami berbagai masalah, kesulitan, ataupun rasa ketidakpastian. Di sinilah letak peranan bimbingan dan konseling (BK), yaitu memberikan bantuan untuk mengatasi masalah tersebut sehingga anakanak dapat belajar lebih berhasil. Dengan begitu pencapaian tujuan pendidikan di sekolah lebih dapat diperlancar.
Trianto (2015: 22) menjelaskan bahwa dilihat dari peran guru BK yang bertugas membimbing siswa dan juga melakukan konseling dengan siswa dimana guru bimbingan dan konseling harus menghadapi siswa yang memunyai sifat yang berbeda-beda, maka guru bimbingan dan konseling harus memiliki sifat-sifat yang dapat membuat siswanya nyaman untuk mendekatinya. Selanjutnya, Slameto (1988: 113) mengemukakan bahwa tugastugas sehubungan peranan guru BK ini adalah:

1. Mengumpulkan data tentang pribadi murid.

2. Mengobservasi tingkah laku murid dalam situasi sehari-hari.

3. Mengenal murid yang memerlukan bantuan khusus.

4. Mengadakan pertemuan/ kontak dengan orang tua baik individu ataupun kelompok untuk memeroleh saling pengertian dalam pendidikan.

5. Membuat catatan-catatan pribadi murid dan menyimpannya dengan baik.

6. Menyelenggarakan bimbingan kelompok atau individual.

Daryanto (2015: 35) menjelaskan bahwa ada beberapa hal yang perlu diperhatikan yang harus dimiliki oleh seorang guru BK:

1. Kualifikasi dan pendidikan guru BK

Untuk menghadapi kebutuhan dewasa ini seorang guru BK sekurang-kurangnya harus seorang sarjana muda. Ia harus memiliki kualifikasi yang memungkinkanya untuk dapat melaksanakan tugas konseling dengan berhasil baik. Diantaranya: kecakapan scholastic, minat terhadap pekerjaanya dan kepribadian yang baik.

2. Kewajiban dan tanggung jawab guru BK

Pada umumnya guru BK bertanggung jawab dalam melaksanakan bimbingan pendidikan (educational guidance) dan bimbingan dalam masalah-masalah pribadi (personal guidance). Iapun harus menetapkan kasus-kasus yang perlu mendapatkan perhatiannya dengan segera dengan jalan meneliti catatan-catatan sekolah, mengadakan pertemuan-pertemuan dengan anggota-anggota staf sekolah lainya, melaksanakan observasi yang dilakukannya sendiri dan menggunakan teknik sosiometrik.

\section{Metode Penelitian}

Penelitian ini dilaksanakan di SMK Negeri 6 Kendari yang bertempat di Jln. Boulevard, Kelurahan Lepo-lepo, Kecamatan Baruga, Kota Kendari, Sulawesi Tenggara. Penelitian ini dilakukan pada bulan April sampai bulan Mei 2017. 
Penelitian ini adalah deskriptif kuantitatif, yaitu memberikan gambaran atau mendeskripsikan suatu fenomena sosial secara statistic untuk menjelaskan karakteritik suatu individu atau kelompok (Syamsudin \& Damiyanti: 2011). Hal ini sesuai dengan tujuan penelitian, yaitu untuk memeroleh informasi atau gambaran tentang Sikap Siswa Terhadap Peran Guru BK Pada Jurusan Geologi Pertambangan di SMK Negeri 6 Kendari.

Populasi dalam penelitian adalah siswa kelas X, XI dan XII Jurusan Geologi Pertambangan yang seluruhnya berjumlah 132. Sampel penelitian diambil menggunakan yeknik proportional random sampling yang berjumlah sebanyak 26 orang. Selain itu untuk memperkuat data penelitian peneliti juga meminta beberapa data dari guru BK dan guru mata pelajaran.

Pengumpulan data penelitian menggunakan teknik angket atau kuesioner. Teknik Kuesioner atau angket merupakan teknik pengumpulan data dengan mengajukan pertanyaan atau pernyataan tertulis kepada responden untuk menjawabnya. Pengumpulan data dilakukan pada sumber data yaitu siswa sebagai sampel penelitian untuk mengevaluasi atau mengetahui sikap siswa terhadap peran guru BK di SMK Negeri 6 Kendari. Data penelitian ini berupa data kuantitatif sehingga analisis data menggunkan statistik deskriptif dan Persentase. Skala pengukuran rentang skor menggunakan skala Likert dengan rentang skor 1 sampai dengan 4.

\section{Hasil Penelitian dan Pembahasan Hasil Penelitian}

Deskripsi sikap siswa secara kognitif mengenai peran guru BK di SMK Negeri 6 Kendari dapat dilihat melalui sajian data pada tabel berikut ini:

Tabel 1

Frekuensi Sikap (kognitif) Siswa Terhadap Peran Guru BK di SMK Negeri 6 Kendari.

\begin{tabular}{|c|c|c|c|}
\hline Kategori & Skor & Siswa & $(\%)$ \\
\hline Baik & $55-67$ & 10 & $38.46 \%$ \\
\hline Cukup Baik & $42-54$ & 16 & $61.53 \%$ \\
\hline Kurang baik & $29-41$ & 0 & 0 \\
\hline Tidak baik & $16-28$ & 0 & 0 \\
\hline Jumlah & & 26 & $100 \%$ \\
\hline
\end{tabular}

Berdasarkan tabel di atas dapat diketahui bahwa $38.46 \%$ atau 10 orang siswa dinyatakan bahwa secara kognitif memiliki sikap yang baik terhadap peran guru BK di sekolah, yaitu dengan perolehan skor berada pada rentang (55-67) pada kategori baik: $61.53 \%$ atau 16 orang siswa dinyatakan memiliki sikap yang cukup baik terhadap peran guru BK di sekolah, yaitu dengan perolehan skor berada pada rentang (42-54) pada kategori cukup baik. Sedangkan rata-rata perolehan skor pada indikator kognitif adalah sebesar 53.5 dan berada pada rentang skor (42-54) pada kategori cukup baik. Dengan demikian, dapat disimpulkan bahwa pada indikator kognitif, sikap siswa terhadap peran guru BK di SMK Negeri 6 Kendari berada pada kategori cukup baik.

Deskripsi sikap siswa secara afektif mengenai peran guru BK di SMK Negeri 6 Kendari dapat dilihat melalui sajian data pada tabel berikut ini:

\section{Tabel 2}

Frekuensi Sikap (afektif) Siswa Terhadap Peran Guru BK di SMK Negeri 6 Kendari.

\begin{tabular}{|c|c|c|c|}
\hline Kategori & Skor & Siswa & $(\%)$ \\
\hline Baik & $34-41$ & 6 & $23.07 \%$ \\
\hline Cukup Baik & $26-33$ & 20 & $76.92 \%$ \\
\hline Kurang baik & $18-25$ & 0 & - \\
\hline Tidak baik & $10-17$ & 0 & - \\
\hline Jumlah & & 26 & $100 \%$ \\
\hline
\end{tabular}

Berdasarkan tabel di atas dapat diketahui bahwa $23.07 \%$ atau 6 orang siswa dinyatakan bahwa secara afektif memiliki sikap yang baik terhadap peran guru BK di sekolah, yaitu dengan perolehan skor berada pada rentang (34-41) pada kategori baik: $76.92 \%$ atau 20 orang siswa dinyatakan memiliki sikap yang cukup baik terhadap peran guru BK di sekolah, yaitu dengan perolehan skor berada pada rentang (26-33) pada kategori cukup baik: Sedangkan secara keseluruhan rata-rata perolehan skor pada indikator afektif adalah sebesar 30.6 berada pada rentang skor (26-33) pada kategori cukup baik. Dengan demikian, dapat disimpulkan bahwa pada indikator afektif, sikap siswa terhadap peran guru BK di SMK Negeri 6 Kendari berada pada kategori cukup baik.

\section{Pembahasan}

Penelitian ini membuktikan bahwa sikap siswa terhadap peran guru BK pada Jurusan Geologi di SMK Negeri 6 Kendari berada pada kategori cukup baik, hal ini dapat dilihat dengan perolehan rerata skor angket sebesar 136.7 berada pada rentang 
skor (109-141) pada kategori cukup baik. Begitu pula jika dilihat dari mayoritas perolehan skor sampel penelitian diketahui $61.53 \%$ atau 16 orang siswa dinyatakan memiliki sikap yang cukup baik terhadap peran guru BK di sekolah di SMK Negeri 6 Kendari.

Trianto (2015) menjelaskan bahwa peran guru BK sebagai tenaga profesional yang telah dipersiapkan oleh lembaga atau instansi pendidikan yang berwenang untuk membantu siswa dalarn memecahkan masalah-masalah yang dihadapi oleh siswa, baik masalah pribadi, sosial, akademik maupun karir. Guru BK dididik secara khusus untuk menguasai kompetensi yang diperlukan bagi pekerjaan bimbingan dan konseling.

Selanjutnya Sarwono (2009) menyatakan bahawa sikap (attitude) merupakan istilah yang mencerminkan rasa senang, atau perasaan biasabiasa saja (netral) dari seseorang terhadap sesuatu. "sesuatu" bisa benda, kejadian, situasi, orang-orang atau kelompok. Kalau yang timbul terhadap sesuatu itu adalah perasaan senang, maka disebut sikap positif, sedangkan kalau perasaan tidak senang, sikap negatif. Kalau tidak timbul perasaan apa-apa berarti sikapnya netral.

Hasil penelitian menunjukan bahwa sikap siswa jurusan geologi pertambangan terhadap guru BK di SMK Negeri 6 Kendari berada pada kategori cukup baik, dapat dikatakan juga bahwa siswa-siswa pada jurusan geologi pertambagan memiliki sikap yang positif terhadap peran guru BK. Ali (2015) menyatakan bahawa sikap adalah predisposisi emosional yang dipelajari untuk merespon secara konsisten terhadap suatu objek. Jika hasil penelitian ini dikaitkan dengan pendapat tersebut maka dapat diasumsikan bahwa sikap positif siswa pada jurusan geologi pertambangan terbentuk dari pengalaman emosional yang diperoleh dari interaksi yang selama ini terjalin antara guru BK dan siswa. Interaksi tersebut bisa berupa interaksi secara langsung, yakni interaksi antara guru BK dan siswa yang terjalin ketika terlibat dalam pelaksanaan program layanan bimbingan dan konseling di sekolah dan juga bisa berupa interaksi secara tidak langsung yakni ketika guru BK berpartisipasi dalam pengambilan kebijakan di sekolah yang berefek langsung kepada siswa. Hal yang sama, juga dikemukakan oleh Azwar (2013) bahwa dalam interaksi sosilanya individu bereaksi membentuk pola sikap tertentu terhadap berbagai objek psikologis yang dihadapinya. Hasil interaksi antara guru BK dan siswa di sekolah secara tidak langsung telah memberikan pengalaman yang memengaruhi komponen-komponen terbentuknya sikap pada diri siswa yaitu komponen kognitif, afektif dan konatif siswa.

Dari komponen afektif, hasil penelitian menunjukan rata-rata perolehan skor sebesar 61.88 berada pada rentang skor (52-67) pada kategori cukup baik. Dengan demikian dapat disimpulkan bahwa pada indikator afektif, sikap siswa terhadap peran guru BK di SMK Negeri 6 Kendari berada pada kategori cukup baik. Dari data tersebut, dapat diketahui bahwa siswa memiliki pengalaman yang positif secara afektif yang memengaruhi sikapnya terhadap peran guru BK. Pengalaman yang dimaksud adalah pengalaman yang memengaruhi emosional siswa yang memberikan penilaian secara subyektif terhadap keinerja guru BK di sekolah. Pengalaman secara emosional memrepresentasikan rasa senang maupun tidak senang yang dimiliki oleh siswa terhadap kinerja guru BK di SMK Negeri 6 Kendari.

\section{Kesimpulan dan Saran Kesimpulan}

Berdasarkan hasil penelitian dan pembahasan yang telah dikemukakan pada bab sebelumnya maka disimpulkan bahwa sikap siswa pada jurusan geologi pertambangan terhadap peran guru BK di SMK Negeri 6 Kendari berada kategori cukup baik yaitu dengan skor rata-rata sebesar 191.1 pada rentang skor (152-197) atau kategori cukup baik.

\section{Saran}

Berdasarkan hasil penelitian, maka peneliti mengemukakan saran-saran sebagai berikut:

1. Kepada siswa agar memertahankan sikap positif yang telah dimiliki terhadap kinerja guru BK yaitu dengan mendukung dan mengkuti setiap program layanan BK yang diselenggarakan oleh guru BK di sekolah.

2. Kepada guru BK SMK Negeri 6 Kendari hendaknya dapat terus melaksanakan dan meningkatkan kualitas dan kuantitas layanan bimbingan kelompok agar dapat membantu siswa dalam mengembangkan segala kemampuan potensi siswa.

3. Kepada guru BK SMK Negeri 6 Kendari hendaknya dapat terus melaksanakan dan meningkatkan kualitas dan kuantitas layanan bimbingan kelompok agar dapat membantu siswa dalam mengembangkan segala kemampuan potensi siswa. 


\section{Daftar Pustaka}

Ali, Mohammad. (2004). Psikologi Remaja (Perkembangan Peserta Didik). Jakarta: PT Bumi Aksara.

Azwar, Saifuddin. (2013). Sikap Manusia (Teori Dan Pengukurannya). Yogyakarta: Pustaka Pelajar.

Daryanto dan Moh. Farid. (2015) .Bimbingan Konseling (Panduan Guru BK dan Guru Umum). Yogyakarta: Gava Media.

Hadiwinarto. (2009). Psikologi (Teori dan Pengukuran). Bengkulu: Rahman Rahim.

Jihad, A. (2013). Evaluasi Pembelajaran. Yogyakarta: Multi Pressindo.

Salahudin, A. (2010). Bimbingan dan Konseling. Bandung: CV. Pustaka Setia.

Sarwono. (2009). Pengantar Psikologi Umum. Jakarta: PT Raja Grafindo Persada.

Sarwono, Sarlito Wirawan. (2014). Pengantar Psikologi Umum. Jakarta: PT Raja Grafindo Persada.

Slameto. 1988. Bimbingan Di Sekolah. Jakarta: Bina Aksara.

Syamsudi, dan Damayanti. (2011). Metode Penelitian Pendidikan Bahasa. Bandung: Remaja Rosdakarya.

Trianto A, Farozin M, dan Ulfa Maria Z. (2015). Hubungan Antara Persepsi Terhadap Guru Bimbingan Dan Konseling Ideal Dengan Minat Konseling Siswa SMA Negeri Yogyakarta. Jurnal Penelitian Bimbingan dan Konseling, Vol 1, No 1. 
Jurnal BENING Volume 4 Nomor 1 Januari 2020

106 | Rosnawati, Sudarmi Suud, Jahada 